\title{
Do delírio do hipocondríaco em uma forma grave da melancolia ansiosa ${ }^{1}-1880^{2}$
}

\author{
Jules Cotard
}

O Dr. Jules Falret e eu estamos acompanhando, há vários anos, uma paciente que apresenta um delírio hipocondríaco bastante singular.

A Srta. X. afirma não ter mais cérebro, nem nervos, nem seios, nem estômago, nem intestinos; restam-lhe apenas a pele e os ossos em um corpo desorganizado (segundo suas próprias palavras). Esse delírio de negação estende-se às idéias metafísicas que, outrora, fundamentavam suas crenças mais arraigadas; ela não tem alma, Deus não existe, nem o diabo tampouco. Como não passa de um corpo desorganizado, a Srta. X. não precisa comer para viver, não poderá morrer de morte natural e existirá eternamente a não ser que seja queimada, pois o fogo representa seu único fim possível.

Assim, ela não cessa de suplicar para que sejam queimados (a pele e os ossos) e já fez várias tentativas de queimar a si própria.

$\mathrm{Na}$ época em que foi internada (em 1874, com 43 anos), havia mais de dois anos que a Srta. X. se

1. Texto lido na Société médico-psychologique, em 28 de junho de 1880 e publicado nos Annales Médico-Psychologiques, set. 1880 , tomo IV.

2. Tradução de Alain François. Revisão técnica pelo Prof. Dr. Mário Eduardo Costa Pereira (Laboratório de Psicopatologia Fundamental/ UNICAMP). 
encontrava nesse estado; tudo teria começado com uma espécie de estalo interior em suas costas que repercutiu em sua cabeça.

A partir daquele momento começou a sofrer de tédio, de angústias que não lhe davam trégua; errava como uma alma penada, pedindo socorro a padres e médicos.

Fizera várias tentativas de suicídio, em decorrência das quais chegou em Vanves. Acreditava-se então danada; seus escrúpulos religiosos a levavam a se acusar de todo tipo de culpa, mais particularmente de não ter feito sua primeira comunhão de modo correto. Deus, dizia, a tinha condenado à eternidade e ela sofria todas as penas do inferno, merecidamente, pois sua vida toda não passara de uma série de mentiras, de hipocrisias e de crimes.

Pouco depois de sua internação, ela guardou essa data, percebeu a verdade - é assim que chama as concepções delirantes negativas que menciono acima e entregou-se, para que essa verdade fosse entendida, a vários tipos de atos de violência, que chamava de seus atos de verdade, mordendo, arranhando, batendo nas pessoas à sua volta.

Há alguns meses, a Srta. X. encontra-se mais calma; a ansiedade melancólica diminuiu de modo sensível; ela ri, brinca, é irônica, malévola e implicante, embora seu delírio não apresente qualquer melhora; a Srta. X. continua sustentando com a mesma energia não ter cérebro, nem nervos, nem intestinos; que comer não passa de um vão suplício e que não há, para ela, outro fim que não o fogo.

A sensibilidade à dor está diminuída na maior parte do corpo, tanto do lado esquerdo quanto do lado direito; poder-se-ia enfiar alfinetes profundamente em sua carne sem que manifeste qualquer sensação de dor. A sensibilidade ao contato e as diversas sensibilidades especiais parecem ter conservado sua integridade.

Quando, há uns vinte anos, o Sr. Baillarger chamou a atenção para o delírio hipocondríaco dos paralíticos, suas afirmações foram objeto de vivas controvérsias; hoje, justiça seja feita a seus trabalhos, temos de reconhecer que um delírio análogo - não disse idêntico - ao delírio hipocondríaco dos paralíticos acomete certos lipemaníacos como a doente cujo caso acabo de expor.

Resta determinar quem são esses lipemaníacos e se formam uma categoria à parte.

Os cinco casos de demonomania mencionados por Esquirol ${ }^{3}$ são notáveis por sua analogia com a paciente acima referida.

A primeira dessas demoniomaníacas teve dois surtos de lipemania. O demônio está em seu corpo e a tortura de mil maneiras diferentes; nunca morrerá. 
O diabo levou o corpo da segunda; ela é uma visão; viverá milhares de anos e o espírito maligno, na forma de uma cobra, tomou posse de seu útero apesar de ela não ter órgãos de geração iguais aos das outras mulheres.

O espírito maligno também levou o corpo da terceira, e deixou um simples simulacro que permanecerá eternamente na Terra. Ela não tem sangue e é insensível (analgesia).

A quarta não evacua há vinte anos, seu corpo é um saco feito com a pele do diabo, cheio de sapos. Não acredita mais em Deus; tem sido a mulher do grande diabo por um milhão de anos. Trata-se de uma espécie de imortalidade retrospectiva.

A quinta tem o coração deslocado, nunca morrerá.

Leuret relata dois casos análogos:

Uma mulher acredita estar danada, seu coração nada mais sente, virou uma estátua de carne imortal; fora possuída pelo demônio e devia ter sido queimada na mesma hora; o passar do tempo tornou isso impossível.

A outra tem a região epigástrica vazia; é danada e não tem mais alma. Mais tarde, ocorreu-lhe o pensamento de que era imortal.

Nenhuma observação feita pelo Sr. Petit, em Maréville ${ }^{4}$. J. acredita estar danada; não tem mais sangue; há de viver eternamente e, para livrá-la da vida, seria preciso cortar-lhe os braços e as pernas. Ela suplica o favor de ser despedaçada.

Poderia citar mais um caso na monografia do Dr. Macario ${ }^{5}$, dois do Dr. Morel ${ }^{6}$ e mais dois em Krafft-Ebing ${ }^{7}$.

Em todos esses doentes, o delírio hipocondríaco apresenta uma analogia muito grande; não têm cérebro, nem estômago, nem coração, nem sangue, nem alma; às vezes nem têm mais corpo.

Alguns se imaginam podres, com cérebro amolecido. É o caso de dois pacientes que estou acompanhando no momento: um acredita ser danado; é o homem danado, o demônio, o Anticristo. Queimará eternamente; não tem mais sangue; seu corpo inteiro está podre; o outro também acredita estar danado; é infame, ignóbil, culpado de todos os crimes; seu cérebro amoleceu, sua cabeça é como uma avelã oca; não tem mais sexo, nem alma e Deus não existe etc.; ele busca se mutilar e se matar por todos os meios possíveis, suplica para ser morto.

$\mathrm{O}$ delírio hipocondríaco é muito diferente daquele que precede ou acompanha o delírio de persecução.
4. Petit. Archives cliniques, p. 59.
5. Macario. Ann. médico-psychologiques, t. I,
6. Morel. Etudes cliniques, t. II, pp. 47 e 118.
7. Krafft-Ebing. Traité de psychiatrie (Obs. II e VII). 
Nos perseguidos, os diferentes órgãos são atacados de mil maneiras, quer por descargas elétricas, por processos misteriosos, ou ainda por influências perniciosas que emanam do ar, da água ou dos alimentos. Mas não há destruição dos órgãos, os quais parecem renascer à medida que os ataques ocorrem.

Nos danados, a obra de destruição é completa; os órgãos não existem mais, o corpo inteiro é reduzido a uma aparência, a um simulacro; além do mais, as negações metafísicas, tão freqüentes nestes últimos, raramente ocorrem nos verdadeiros perseguidos que são, em sua maioria, grandes ontologistas.

Não raro acrescenta-se às idéias hipocondríacas a de imortalidade que, em alguns casos e segundo uma certa lógica, parece decorrer dessas.

Certos doentes afirmam não poder morrer por seu corpo não se encontrar em condições comuns de organização e que se lhes fosse facultado morrer, já teriam morrido há muito; seu estado não é de vida nem de morte; são mortos vivos. Nestes, a idéia de imortalidade é realmente, por mais paradoxal que possa parecer, uma idéia hipocondríaca; trata-se de um delírio triste ligado ao organismo; gemem por causa de sua imortalidade e pedem para ser livrado dela. A idéia de imortalidade às vezes encontrada como delírio de grandeza nos perseguidos crônicos megalômanos é muito diferente.

Conheço um que pretende que a natureza de sua organização se deve a privilégios a ele concedidos por Napoleão I, em 1804 (26 anos antes do nascimento do paciente), e que tem certeza de não morrer nunca.

Outro está convencido de que será levado para o céu como o profeta Elias e de que nunca morrerá.

Se os doentes cujo caso estou mencionando diferem de modo tão patente dos perseguidos ${ }^{8}$, aproximam-se muito, em compensação, dos melancólicos ansiosos; estão num estado de angústia e de ansiedade intenso; gemem, não param de falar, repetem incessantemente as mesmas queixas e imploram por socorro: suas idéias hipocondríacas não parecem senão uma interpretação delirante das sensações doentias que experimentam os doentes acometidos por melancolia ansiosa comum. Estes se queixam de sentir suas cabeças vazias, de um embaraço na região precordial, de não terem mais sentimentos, de não amarem mais nada, de não conseguirem mais rezar, de duvidarem da bondade de Deus; alguns até se queixam de não conseguir mais sofrer; por fim, estão convencidos de que nunca se curarão. Os doentes aos quais me refiro não têm mais cérebro; seu coração estourou (numa observação de Krafft-Ebing), não têm mais alma; Deus não existe mais; sofrerão eternamente sem nunca conseguir morrer; enfim, são,

8. Para maior clareza omiti a menção a casos mistos que, aqui também, estabelecem transiçōes graduais entre as diferentes formas vesânicas. Tais casos são bastante freqüentes. 
na sua maioria, analgésicos. Poder-se-ia espetá-los, beliscá-los sem que demonstrem a menor sensação de dor e é comum eles se mutilarem de modo assustador.

A melancolia ansiosa comum é uma sintomatologia freqüente nas vesânias de surto ou intermitentes que, geralmente, acaba curando.

O mesmo não acontece quando o delírio hipocondríaco se acrescenta a esse quadro; nesse caso, o prognóstico é muito mais grave. Às vezes, isso ocorre já no primeiro surto, mas, via de regra, o delírio hipocondríaco só se desenvolve no segundo ou terceiro surto e o estado do doente torna-se, em geral, crônico.

Krafft-Ebing, contudo, cita dois casos de cura; encontrei outro também em Leuret.

Vale salientar que todos os doentes acometidos por um delírio hipocondríaco com idéias de imortalidade eram tomados por idéias de danação, de possessão diabólica, enfim, apresentavam os sinais de demonomania ou de loucura religiosa.

Não encontrei casos rigorosamente semelhantes nas poucas demoniografias que pude consultar; talvez devêssemos relacionar esta doença antes aos alienados vagabundos que parecem estar à origem da lenda do judeu errante (Cartaphilus, circa 1228, Ahasverus, 1547; Isaac Laquedem, 1640), que se sentiam culpados de uma ofensa contra Jesus Cristo e condenados a vagarem na terra até o dia do juízo final9 ${ }^{9}$.

Nos últimos séculos, vários tipos de loucura têm sido designados com o termo de possessão demoníaca; a maior parte dos casos que chegaram até nós pertencem à histeromania epidêmica ou ao delírio de perseguição. Será preciso estabelecer uma nova categoria de loucura religiosa que se desenvolve no que estou propenso a chamar de melancolia ansiosa grave?

Caso essa espécie de lipemania mereça destaque, seria reconhecida pelos seguintes sinais:

$\left.1^{2}\right)$ Ansiedade melancólica;

$2^{2}$ ) idéia de danação ou de possessão;

$3^{2}$ ) propensão ao suicídio e às mutilações voluntárias;

$\left.4^{0}\right)$ analgesia;

$\left.5^{2}\right)$ idéias hipocondríacas de não-existência ou de destruição de vários órgãos, do corpo inteiro, da alma, de Deus etc.;

$\left.6^{2}\right)$ idéia de nunca conseguir morrer.

9. Encyclopédie des sciences religieuses, art. Juif Eerrant. "Pode-se considerar esse destino (a imortalidade), diz o Sr. Gaston Paris, quer como uma recompensa, quer como um castigo..." Essa mesma diferença se repete entre a imortalidade dos megalômanos e a dos hipocondríacos ansiosos, como indiquei acima. 